\title{
Pembentukan Karakter Islami Melalui Budaya Religius (Studi Kasus di MI Al Huda Kedonglo Ngronggot Nganjuk)
}

\author{
Miftah Kusuma Dewi \\ Institut Agama Islam Pangeran Diponegoro Nganjuk \\ E-mail: miftakusuma978@gmail.com
}

\begin{abstract}
Abstrak: Perkembangan zaman dengan kecanggihan teknologi yang begitu cepat memiliki dampak besar bagi kehidupan. Walaupun perkembangan teknologi sangat bermanfaat bagi manusia tetapi juga tidak sedikit memiliki dampak buruk. Perkembangan yang semakin cepat ini perlu adanya filter/penyaring supaya manusia dapat menggunakan teknologi dengan benar. Maka sejak dini anak diajarkan tentang pendidikan karakter supaya dapat berperilaku dengan baik. Penting sekali membentuk karakter anak melalui metode pembiasaan di lingkungan keluarga, sekolah dan tempat tinggal dengan nilai-nilai kebaikan, dengan pembiasaan tersebut karakter akan tumbuh dan berkembang secara positif sesuai ajaran Islam. Penelitian ini bertujuan untuk mendiskripsikan pendidikan karakter Islami melalui pembiasaan religius. Penelitian ini menggunakan pendekatan kualitatif deskriptif. Sedangkan data kualitatif diperoleh dari wawancara dengan guru dan kepala madrasah, observasi dan dokumentasi. Hasil penelitian yang diperoleh tentang pembiasan-pembiasaan religius yang diterapkan adalah pembiasaan (3S) Senyum, Salam dan Sapa, baca senyap, sholatdhuha berjamaah, SKL madrasah, shalatdhuhur berjamaah dan ekstra kerohanian. Sedangkan mengenai pendidikan karakter Islami melalui pembiasaan religius adalah menerapkan pembiasan religius yang dilakukan setiap hari sebagai proses pembentukan karakter anak untuk berperilaku mulia, taat ibadah, jujur, toleran, peduli lingkungan, bertanggungjawab dan menjadi pondasi akidah bagi anak.
\end{abstract}

Kata Kunci: Pendidikan Karakter Islami, Pembiasaan Religius

\begin{abstract}
The rapid technological sophistication and changes have a big impact on life. Although technological developments are very beneficial for humans, they also have a bad impact. All this requires a filter so that humans can use technology properly. From an early age children are taught about character education so that they could behave well. It is very important to shape children's character through the method of habituation in such environments as family, school and surrounding community with good values. Through such habituation the character will grow and develop positively in accordance with the Islamic teachings. This study aims to describe Islamic character education through religious habituation. This research uses a descriptive qualitative approach. Meanwhile, qualitative data were obtained from interviews with teachers and
\end{abstract}


principals of madrasa, observation and documentation. The results of the research regarding the applied religious habits are so-called $3 \mathrm{~S}$ (senyum, salam and sapa) silent reading, dhuha prayer in congregation, madrasah SKL, dhuhur prayer in congregation and extra-curricular spiritual activities. Meanwhile, the Islamic character education through religious habituation is performing religious activities every day as a process of building children's character to behave well, be obedient, honest, tolerant, environmental, responsible and become the foundation of children's faith.

Keywords: Islamic Character Education, Religious Habit

\section{Pendahuluan}

Perkembangan teknologi semakin hari semakin pesat dan tidak dapat dicegah. Teknologi yang berkembang memiliki dua dampak bagi kehidupan manusia yaitu dampak baik dan buruk. Dengan adanya teknologi kita dapat mengetahui informasi dengan cepat. Sedangkan dampak buruk dari teknologi juga tidak dapat dipandang remeh. Ribuan kasus amoral menimpa anak-anak, remaja dan dewasa bahkan hampir semua elemen bangsa. Hampir tiap hari, media social dan elektronik, merekam banyak kasus pelanggaran terhadap ajaran agama, hukum dan akhlak. Contoh kasus tersebut adalah perampokan, pembunuhan, fitnah, narkoba, pelacuran, pencurian korupsi dan jauh dari praktik ibadah yang terjadi hampir di seluruh pelosok negeri

Teknologi yang berkembangmemerlukan filter/penyaring untuk dapat dikonsumsi oleh anak zaman sekarang. Penyaring yang dibutuhkan anak adalah berupa pendidikan tentang pengetahuan akan hal yang baik dan buruk. Pengajaran akan kebaikan dan keburukan perlu ditanamkan sejak dini agar dapat membentuk karakter anak. Pembentukan karakter dan kepribadian anak sesuai dengan nilai keagamaan menjadi sebuah kebutuhan dan keharusan. Maka dari itu, penting sekali membentuk nilai-nilai karakter melalui metode pembiasaan di lingkungan keluarga, sekolah dan tempat tinggal dengan nilai-nilai kebaikan, maka nilai-nilai karakter anak akan tumbuh dan berkembang secara positif sesuai ajaran pendidikan agama Islam.

Pendidikan Islam memiliki peranan besar terhadap perkembangan anak, baik pada usia dini sampai mereka tumbuh dewasa. Pendidikan Islam merupakan pendidikan yang menonjolkan nilai ketuhanan dan nilai kemanusiaan. Nilai-nilai ketuhanan dan kemanusiaan yang berlangsung sejak dini mampu membentuk kepribadian dan karakter anak sehingga mempunyai pengaruh yang kuat sepanjang hidupnya. Dalam Islam pendidikan karakter sama dengan akhlak yaitu kecenderungan jiwa untuk bersikap/bertindak secara otomatis. Akhlaq yang sesuai ajaran Islam disebut dengan akhlaqulkarimah atau akhlaq mulia. Akhlak pada anak sebaiknya diajarkan dengan pembiasaan sejak dini.

Pendidikan karakter merupakan suatu sistem penanaman nilai-nilai perilaku (karakter) pada warga sekolah yang meliputi komponen pengetahuan, kesadaran atau kemauan, dan tindakan untuk melaksanakan nilai-nilai tersebut, baik terhadap Tuhan Yang Maha Esa, diri sendiri, sesama, lingkungan maupun kebangsaan sehingga menjadi manusia insan kamil. Namun, saat ini ada banyak anggapan bahwa pelaksanaan pendidikan karakter belum optimal. 
Hal tersebut disebabkan karena sistem pendidikan yang diterapkan lebih menekankan pada pengembangan intelektual. ${ }^{1}$

Salah satu ayat yang menerangkan tentang pendidikan karakter adalah Q.S Luqman ayat 12-14 sebagaimana berbunyi:

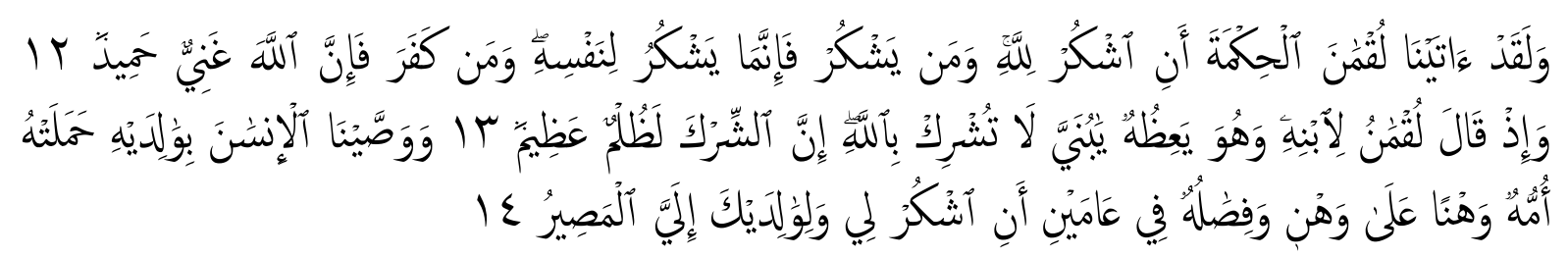

"Dan sesungguhnya telah Kami berikan hikmah kepada Lukman, yaitu: "Bersyukurlah kepada Allah. Dan barang siapa yang bersyukur (kepada Allah), maka sesungguhnya ia bersyukur untuk dirinya sendiri; dan barang siapa yang tidak bersyukur, maka sesungguhnya Allah Maha Kaya lagi Maha Terpuji". Dan (ingatlah) ketika Lukman berkata kepada anaknya, di waktu ia memberi pelajaran kepadanya: "Hai anakku, janganlah kamu mempersekutukan (Allah) sesungguhnya mempersekutukan (Allah) adalah benar-benar kelaliman yang besar". Dan Kami perintahkan kepada manusia (berbuat baik) kepada dua orang ibu-bapaknya; ibunya telah mengandungnya dalam keadaan lemah yang bertambahtambah, dan menyapihnya dalam dua tahun. Bersyukurlah kepada-Ku dan kepada dua orang ibu bapakmu, hanya kepada-Kulah kembalimu”

Ada beberapa unsur pendidikan karakter dari segi materi yang disimpulkan dari AlQur'an Surat Luqman ayat 12-14. Karakter tersebut terangkum dalam karakter religius, yaitu sikap dan perilaku yang patuh dalam melaksanakan ajaran agama yang dianutnya, toleran terhadap pelaksanaan ibadah agama lain, dan hidup rukun dengan pemeluk agama lain ${ }^{2}$.

Karakter Islami ini dapat dididik dengan pembiasaan sehari-hari di sekolah. Pendidikan karekter dapat dibiasakan pada siswa dengan menerapkan nilai-nilai agama yang sejalan dengan berkembangnya interaksi anak dengan lingkungannya. Sekolah sebagai lingkungan untuk berinteraksi ke dua anak dan tempat di mana anak belajar bersosialisasi dengan temanteman sebayanya dan orang dewasa di luar rumah. Dalam interaksi tersebut anak-anak mengenal berbagai macam perilaku dan pengetahuan baik positif ataupun negatif. Pengalaman-pengalaman yang peroleh ketika berinteraksi di sekolah lebih banyak dan bervariasi dibanding dengan pengalaman yang merekan dapat rumah. Perilaku yang beraneka ragam tersebut kita pahami sebagai sarana pembelajaran untuk perkembangan moral anak. Oleh sebab itu pengalaman yang mereka dapat harus didampingi dengan pengalaman nilainilai agama yang berperan penting untuk memilah antara pengalaman yang harus dicontoh atau tidak.

Sekolah memiliki peran dalam pembentukan karakter anak yang terletak pada programprogram pembiasaan yang dilaksanakan setiap hari. pembiasan yang diprogramkan sekolah adalah wadah bagi anak untuk mengenal, mengetahui dan menerapkan perilaku-perilaku yang

\footnotetext{
${ }^{1}$ Abdullah Munir, Pendidikan Karakter Membangun Karakter anak sejak dari Rumah (Yogyakarta: Pedagogia, 2010), 72.

${ }^{2}$ Pupuh Fathurrohman, dkk., Pengembangan Pendidikan Karakter (Bandung: Refika Aditama, 2013), 19.
} 
bernilai islami yang mencerminkan akhlak seorang muslim. Pembiasaan yang dilakukan sejak dini akan berpengaruh bagi pertumbuhan dan perkembangan anak selanjutnya baik dari pola pikir dan perilakunya. Salah satu contoh pembiasaan religius yang dilakukan disekolah adalah mengucapkan salam saat bertemu dan saat berpisah dengan guru dan temannya, mencium tangan guru sebagai orangtuadisekolah saat bersalaman, dan ini akan menjadi kebiasaan baik dikemudian hari.

Penelitan ini dilakukan di Madrasah Ibtidaiyah Al Huda Kedonglo adalah salah satu Madrasah Swasta yang berdiri di dusun Kedunglo desa Cengkok kecamatan Ngronggot. Madrasah ini bukan satu-satunya madrasah ibtidaiyah yang berada di desa Cengkok, namun Madrasah ini merupakan salah satu madrasah yang berprestasi baik di tingkat kecamatan dan kabupaten hingga provinsi. Bermacam-macam prestasi diraih mulai dari ilmu pengetahuan sampai ilmu keagamaan dan juga kreativitas anak. Siswa Madrasah ini tidak semua berasal dari keluarga mampu dan memiliki keagamaan yang baik, tetapi di madrasah ini anak dilatih dengan proses pembiasaan religius agar dapat memunculkan karakter islami pada anak.

Berdasarkan uraian pada latar belakang di atas dan untuk mendalami penelitian ini, dirumuskan masalah tentang bagaimana pembiasan religius yang diterapkan di madrasah dan bagaimana pendidikan karakter Islamimelalui pembiasaan religius di MI Al Huda KedongloNgronggotNganjuk.Dengan permasalahan tersebut, tujuan penelitian ini adalah untuk mengetahuipembiasan religius yang diterapkan di Madrasah dan pendidikan karakter Islami melalui pembiasaan religius di MI Al Huda KedongloNgronggotNganjuk.

Penelitian ini menggunakan pendekatan kualitatif diskriptif, yaitu prosedur penelitian yang mengasilkan data deskriptif berupa kata-kata tertulis atau lisan dari orang-orang dan perilaku yang dapat diamati. ${ }^{3}$ Artinya penulis hanya menggambarkan situasi yang efektif tentang data yang diperolehdan menganalisa secara kritis terhadap permasalahan yang dikaji. Penelitian ini menggunakan data kualitatif yang diperoleh dari guru dan kepala sekolah berdasarkan wawancara, observasi dan dokumentasi dengan melakukan observasi secara langsung di lapangan menggunakan instrument pedoman pengamatan, serta pedoman wawancara. Dengan observasi secara langsung, maka peneliti akan mendapatkan gambaran mengenai kondisi serta hal-hal apa saja yang terjadi selama kegiatan pembiasaan religius. Untuk menganalisis data menggunakan analisis deskriptif dengan pendekatan metodologi kualitatif. Yaitu analisis data dilakukan dengan menata dan menelaah secara sistematis dari semua data yang diperoleh

\section{Praksis Pendidikan Karakter Islami di MI al-Huda Kedunglo}

Karakter itu berkaitan dengan kekuatan moral yang positif, dan bukan konotasi negatif. Dan orang berkarakter adalah orang yang mempunyai kualitas moral yang positif. Dengan demikian pendidikan adalah membangun karakter, yang secara implisit mengandung arti membangun sifat atau pola perilaku yang didasari atau berkaitan dengan dimensi moral yang

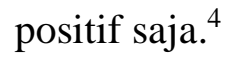

Sedangkan pendidikan karakter merupakan proses untuk mengembangkan pada diri setiap peserta didik kesadaran sebagai warga bangsa yang bermartabat, merdeka, dan

\footnotetext{
${ }^{3}$ Lexi J. Moeleong, Metodologi Penelitian Kualitatif (Bandung: Remaja Rosdakarya, 2002), 3.

${ }^{4}$ Mansur Muslich, Pendidikan Karakter Menjawab Tantangan Krisis Multidimensional (Jakarta: Bumi Aksara, 2011), 70 .
} 
berdaulat serta berkemauan untuk menjaga dan mempertahankan kemerdekaan dan kedaulatan tersebut. ${ }^{5}$ Pendidikan karakter mengajarkan kebiasaan cara berpikir dan perilaku yang membantu individu untuk hidup dan bekerja bersama sebagai keluarga, masyarakat, dan bernegara dan membantu mereka untuk membuat keputusan yang dapat dipertanggungjawabkan.

Pendidikan karakter dalam Islam adalah sebagai wahana pembentukan manusia yang bermoralitas tinggi. Di dalam ajaran Islam moral atau akhlak tidak dapat dipisahkan dari keimanan. Keimanan merupakan pengakuan hati. Akhlak adalah pantulan iman yang berupa perilaku, ucapan, dan sikap atau dengan kata lain akhlak adalah amal saleh. Iman adalah maknawi (abstrak) sedangkan akhlak adalah bukti keimanan dalam bentuk perbuatan yang dilakukan dengan kesadaran dan karena Allah semata. ${ }^{6}$

Pendidikan karakter dapat dilakukan daengan proses pembiasaan yang dilakukan disekolah. Sebagaimana kita ketahui, anak menghabiskan waktu siangnya 5 jam untuk sekolah normal dan 8 jam untuk sekolah fullday di lingkungan sekolah. Dan ini berjalan setiap hari selama masa belajrnya. Jadi sekolah memiliki peran penting untuk membiasakan anak dalam hal kegiatan religius untuk mendidik karakter islai mereka.

Dalam penelitian ini adapun pembiasaan religius yang dibiasakan di MI Al Huda Kedonglo adalah sebagai berikut:

1. Senyum Sapa Salam

Pembinaan karakter siswadalam sikap senyum sapa salam dapat dilakukan melalui 3 hal yakni:

a. Keteladanan, yakni perilaku serta sikap guru dalam memberikan contoh baik dapat menjadi panutan bagi peserta didik. Karena faktor penting dalam mendidik adalah terletak pada "keteladanannya".

b. Kedisiplinan, yakni merupakan kemampuan suatu bentuk ketaatan dan peraturan serta sanksi yang berlaku dalam lingkungan sekolah.

c. Pembiasaan, yakni sesuatu yang dapat diarahkan pada upaya pembudayaan aktifitas tertentusehingga menjadi aktifitas yang terpola atau tersistem dan dilakukan secara terus menerus. ${ }^{7}$

Pembiasaan karakter 3S selalu dibiasakan di MI Al Huda Kedonglo setiap pagi. Para guru dijadwalkan untuk menyambut kedatangan anak setiap pagi. Pembiasaan ini mendidik karakter Islami anak agar selalu santun pada orang tua dan membiasakan bersalaman dan menyapa orang yang mereka temui. Pembiasaan ini membentuk anak peduli terhadap sesama dan meninggalkan sifat acuh tak acuh dan juga sifat sombong saat bertemu orang lain.

\footnotetext{
${ }^{5}$ Darmiyati Zuchdi, Pendidikan Karakter dalam Perspektif Teori dan Praktik (Yogyakarta: UNY Press, 2011), 159.

${ }^{6}$ Agus Zainul Fitri, Reinventing Human Character: Pendidikan Karakter Berbasis Nilai \& Etika di Sekolah (Jogjakarta: Ar-Ruzz Media, 2010), 43.

7 Anike H. Pongoliu, "Pembinaan Karakter Siswa Dalam Membentuk Sikap 3S (senyum salam dan sapa)", Jurnal Pasca Sarjana Universitas Negeri Gorontalo, Vol. 2, No. 2 (2017), 201-205.
} 


\section{Pembiasaan Baca Senyap}

Baca senyap dapat disebut juga dengan membaca dalam hati. pada saat membaca dalam hati pembaca menggunakan ingatan visual dan melibatlan keaktifan mata dan ingatannya. Istilah baca senyap diberikan oleh kepala madrasah untuk kegiatan pembiasaan membaca bebas dipagi hari sebelum bel berbunyi. Tujuan dari baca senyap ini addalah agar memberikan kesadaran anak akan pentingnya program literasi. Kegiatan baca senyap ini yang dibaca oleh anak-anak adalah pelajaran yang akan diajarkan hari itu. Selain untuk membiasakan anak dengan program literasijuga membiasaakananak agar saat datang kesekolah sebelum masuk pelajaran anak tidak langsung bermain-main tetapi program baca senyap ini akan melatih anak gemar membaca.

\section{Pembiasaan sholatdhuha berjamaah}

Pembiasaan sholatdhuha berjamaah dilakukan setiap pagi sebelum pelajaran dimulai. Setelah anak datang dan melakukan pembiasan baca senyap, ketika bel masuk berbunyi semua anak mulai dari kelas 1sampai kelas 6 melakukan sholatdhuha berjamaah dan melakukan doa-doa setelah sholat yang dibimbing oleh iman dan didampingi wali kelas masing-masing. Pembiasaan ini dapat menumbuhkan akhlak kepada Allah untuk selalu taat beribadah padaNya.

Pembiasaan sholatdhuha merupakan salah satu faktor dari kepatuhan serta tawadhu' para siswa dalam menjalani rutinitas ini. Sebagai sebuah kebiasaan yang membutuhkan ketelatenan siswa ini maka menjadi sebuah fenomena yang mampu mengiring siswa untuk lebih teliti dalam berbagai hal. ${ }^{8}$ Pembiasaan ini akan menjadi salah satu ciri Madrasah dan menjadi kewajiban siswa untuk lebih bertanggung jawab menjalankan ibadahnya.

\section{SKL Madrasah}

SKL adalah kepanjangan dari Standar Kompetensi Lulusan. Standar Kompetensi adalah suatu ukuran kompetensi yang harus dicapai peserta didik setelah mengikuti suatu proses dalam satuan pendidikan tertentu. Sedangkan SKL Madrasah yang dimaksud dalam salah satu program pembiasaan religius di MI Al Huda Kedongloadalah Standar Kompetensi kelulusan Madrasah melalui program-program hafalan dan praktek ibadah. SKL ini dibuat oleh kepala madrasah dengan tujuan agar siswa lulusan dari madrasah menguasai hal-hal yang sesuai dengan visi- misi madrasah. SKL ini diperuntukkan untuk semua murid dari kelas 1sampai kelas 6 dan akan di ujikan di setiap semester disetiap jenjang. Selanjutnya juga diujikan diakhir ujian kelas 6 sebagai syarat kelululusanpendidikan di madrasahibtidaiyah Al Huda Kedonglo.

Penjabaran dari SKL MI Al Huda Kedonglo sebagaimana yang telah dipaparkan Ibu Roihana sebagai Kepala madrasah adalah sebagia berikut:

a. Kelas 1menghafalkan surah al fatihah, an nass, al falaq, al ikhlas, dan asmaulhusna.

b. Kelas 2 memahami dan menghafalkan syarat wudlu, rukun wudlu, sunnah wudlu, halhal yang membatalkan wudlu, doa sesudah wudlu, mempraktekkan wudlu, dan memahami hal-hal yang berkaitan dengan tayamum

\footnotetext{
${ }^{8}$ Siti Nor Hayati, "Manfaat Sholat Dluha dalam Pembentukan Akhlakul Karimah Siswa", Jurnal Spiritualita, Vol. 1, No. 1 (Juni 2017).
} 
c. Kelas 3 memahami syarat sholat, rukun sholat, sunnah sholat, hal-hal yang membatalkan sholat dan mempraktekkannya, melafalkan wiridan, dan menghafalkan doa sesudah sholat.

d. Kelas 4 menghafalkan surah yasin.

e. Kelas 5 menghafalkan bacaan tahlil dan dapat mengimami tahlil.

f. Kelas 6 menghafal surah yasin, menghafal surah al waqiah, melafalkan tahlil dan di akhir semester diadakan ujian untuk SKL Madrasah dengan materi yang telah dipelajari dari kelas 1 sampai kelas 6

5. Sholat Dhuhur berjamaah

Setiap hari setelah jam pelajaran selesai semua siswa dari kelas 1 dampai kelas 6 dibiasakan melaksanakan sholatdhuhur berjamaah. Setelah sholatberjamaah diadakan kultum yang diisi oleh guru digilir bergantian setiap hari. Materi kultumyang disampaikan adalah mengenai cerita-cerita inspiratif penuh keteladanan dan tidak diambil dari materi pembelajaran. Tujuannya agar menambah pengetahuan anak tentang manfaat bersikap baik, sopan santun, dan hal-hal kebaikan dimuka bumi ini.

6. Kegiatan ekstra kerohanian

a. Tahfidz

Ekstra tahfidz ini dikhususkan bagi anak-anak yang berminat untuk menghafal alQuran dan konsentrasi pada perlombaan. Kegiatan tahfidz dilakukan diwaktu istirahat dan langsung dibimbing oleh kepala madrasah. Setiap jam istirahat siswa yang berminat dengan hafalan al-Quran diminta untuk menghadap kepala madrasah dan stor hafalan semampu mereka. Ekstra ini juga merupakan salah satu wadah dan strategi madrasah untuk menyiapkan anak jika ada perlombaan MTQ mereka sudah siap untuk mengikutinya.

b. Pidato 3 bahasa

Kegiatan ekstrakurikuler pidato 3 bahasa yang dilaksanakan di MI Al Huda Kedonglo adalah pidato bahasa Indonesia, Bahasa Arab, dan Bahasa Inggris. Dari kegiatan ekstra pidato 3 bahasa ini banyak kejuaraan di raih baik dari tingkat kecamatan sampai tingkat provinsi.

c. Hadroh

Ekstrakurikuler kerohanian selanjutnya adalah hadroh. Manfaat dari Kegiatan selain untuk menimbulkan bakat seni pada anak jug membentuk rasa kebersamaan dan melatih kekompakan sesama anggota grup.

\section{Pembentukan KarakterIslamimelalui Budaya Religius}

Dalam Islam karakter identik dengan akhlak mulia. Karakter ini merupakan hasil dari proses penerapan ibadah dan muamalah yang dilandasi dengan aqidah. Karakter mulia pada diri manusia tidak akan terwujud dengan sendirinya apabila tidak memiliki aqidah yang kuat yang ditanamkan pada diri sejak dini. Penanaman akhlak mulia sejak dini dilakukan dengan pembiasan-pembiasan baik dari segi ibadah dan muamalah. Jika seorang muslim memiliki iman yang kuat maka perilaku sehari-hari akan terwujud akhlak mulia 
Konsep pendidikan karakter sebenarnya telah ada sejak zaman RasulullahSAW. Hal ini terbukti dari perintah Allah bahwa tugas pertama dan utama Rasulullah adalah sebagai penyempurna akhlak bagi umatnya. Pembahasan substansi makna dari karakter sama dengan konsep akhlak dalam Islam, keduanya membahas tentang perbuatan prilaku manusia. AlGhazali menjelaskan jika akhlak adalah suatu sikap yang mengakar dalam jiwa yang darinya lahir berbagai perbuatan dengan mudah dan gampang tanpa perlu adanya pemikirandan pertimbangan $^{9}$

Pendidikan karakter Islami adalah suatu usaha yang disengaja untuk membantu seseorang sehingga ia dapat berfikir, memahami, memperhatikan, berucap, bertindak dan mengamalkan nilai-nilai etik sesuai dengan ajaran Islam. Dengan kata lain, pendidikan karakter yang Islami sama dengan pendidikan akhlak muliabaik dalam hubungan dengan Allah, sesama manusia, diri sendiri maupun dengan lingkungan.

Pendidikan karakter yang Islami paling tidak dapat dilakukan dengan beberapa metode; qudwah (keteladanan), pembiasaan (tadrib), pencegahan (nahyu), apresiasi (tsawab) dan sanksi ("iqab). Melalui qudwah sesorang menjadi "role model" bagi pihak lain dan pihak lain dapat meneladani dan meniru karakter baik-nya. Contohnya, karakter mulia Rasulullah SAW menjadi suri teladan bagi umatnya dan umat sejatinya meniru perilaku mulia Rasulullah SAW (Q.S. al-Ahzab: 21). Melalui tadrib (pembiasaan) seseorang dibiasaakan sejak kecil untuk mengamalkan nilai perilaku mulia; taat ibadah, jujur, toleran, peduli lingkungan, bertanggungjawab dan lain sebagainya. Pembiasaan berperilaku mulia sejak kecil, in syaa Allah, akan membentuk kepribadian seseorang berperilaku mulia. ${ }^{10}$

Pola pikir anak, cara memahami segala sesuatu dan bagaimana anak berucap dan bertindak perlu adanya pendidikan dari orang dewasa ataupun langsung dari lingkungannya. Sekolah merupakan lingkungan aman untuk mendidik anak memahami segala hal dan tentunya dalam pendidikan akhlak atau kareakter anak. Proses yang dapat dilakukan dilingkungan sekolah adalah dengan cara pembiasan-pembiasaan yang dilakukan setiap hari.

Pembiasaan islami atau religius dengan sendirinya akan membentuk karakter Islami. Sebagaimana telah dilakukan penelitian di MI Al Huda Kedonglopembiasaaanreligius tersebut diantaranya pembiasaan senyum sapa salamyag rutin dilakukandipagi hari untuk menyabut kedatangan anak-anak, baca senyapmengenai pelajaran yang akan dilakukan setiap hari sebelum bel berbunyi, sholatdhuha berjamaah dengan ditabahkultum cerita isnpiratif atau tentang keteladanan, SKL madrasah yang berisi hafalan dan amalan ibadah, shalatdhuhurberjamaah dan beberapa ekstra kerohanian. Pembiasaan-pembiasan ini merupakan usaha sekolah untuk mendidik karakter islami.

Penanaman karakter pada anak sejak dini berarti ikut mempersiapkan generasi bangsa yang berkarakter, mereka adalah calon generasi bangsa yang diharapkan mampu memimpin bangsa dan menjadikan negara yang berperadaban, menjunjung tinggi nilai-nilai luhur bangsa dengan akhlak dan budi pekerti yang baik serta menjadi generasi yang berilmu pengetahuan tinggi dan menghiasi dirinya dengan iman dan taqwa. Karakter seseorang muncul dari sebuah

\footnotetext{
${ }^{9}$ Abidin Ibnu Rusn, Pemikiran Al-Ghazali Tentang Pendidikan (Yogyakarta: Pustaka Pelajar, 1998), 99.

10 Syabuddin Gade, Gema Jumat, 14 September 2018 diakses dari https://baiturrahmanonline.com/khutbahjumat/pendidikan-karakter-islami/
} 
kebiasaan yang berulang-ulang dalam waktu yang lama serta adanya teladan dari lingkungan sekitar. Pembiasaan itu dapat dilakukan salah satunya dari kebiasaan prilaku. ${ }^{11}$

Dengan adanya pendidikan karakter Islami, anak dengan sendirinya akan mengetahui mana perbuatan yang baik dan yang buruk, perbuatan yang bermanfaat dan yang tidak bermanfaat walaupun dengan terus adanya perkembangan zaman yang begitu pesat dan perkembang teknologi yang tidak bisa dihentikan. Pembiasaan religius yang dilakukan setiap hari menjadi pembiasaan amalan anak untuk berperilaku mulia, taat ibadah, jujur, toleran, peduli lingkungan, bertanggungjawab. Pendidikan karakter Islami ini menjadi salah satu fondasi untuk membangun akidah yang kuat.

\section{Penutup}

Pembiasaan menjadi salah satu metode pembentukan karakter anak. Guru yang sabar mendidik siswa menjadi contoh teladan untuk pendidikan karakter. Pendidikan karakter Islamimenjadi perhatian penting sekolah dalam rangka mempersiapkan generasi yang berkualitas dan berakhlakulkarimah. Pembiasaan religius yang dilakukan di MI Al Huda Kedonglo adalah pembiasaan senyum sapa salam, baca senyap, sholatdhuha berjamaah, SKL madrasah, shalatdhuhur berjamaah dan ekstra kerohanian.

Pendidikan karakter Islami MI Al Huda Kedonglo dilakukan dengan melakukan pembiasaan-pembiasan reigius. Pembiasaan religius yang dilakukan setiap hari menjadi pembiasaan amalan anak untuk berperilaku mulia, taat ibadah, jujur, toleran, peduli lingkungan, bertanggungjawab. Pedidikan karakter Islami melalui pembiasaan religius menjadi salah satu fondasi untuk membangun akidah yang kuat bagi anak.

\section{Daftar Rujukan}

Ainiyah, Nur. "Pembentukan Karakter melalui Pendidikan Agama Islam" Jurnal Al-Ulum (Jurnal Studi-Studi Islam) IAIN Gorontalo, Volume. 13 Nomor 1, Juni 2013.

Fathurrohman, Pupuh dkk. Pengembangan Pendidikan Karakter, Bandung: Refika Aditama, 2013.

Fitri, Agus Zainul. Reinventing Human Character: Pendidikan Karakter Berbasis Nilai \& Etika di Sekolah, Jogjakarta: Ar-Ruzz Media, 2010.

Gade, Syabuddin. Gema Jumat, 14 September 2018 diakses dari https://baiturrahmanonline.com/khutbah-jumat/pendidikan-karakter-islami/

Ibnu Rusn, Abidin. Pemikiran Al-Ghazali Tentang Pendidikan, Yogyakarta: Pustaka Pelajar, 1998.

Moeleong, Lexi J. Metodologi Penelitian Kualitatif, Bandung: Remaja Rosdakarya, 2002.

Munir, Abdullah. Pendidikan Karakter Membangun Karakter anak sejak dari Rumah, Yogyakarta: Pedagogia, 2010.

Muslich, Mansur. Pendidikan Karakter Menjawab Tantangan Krisis Multidimensional, Jakarta: Bumi Aksara, 2011.

Pongoliu, Anike H. "Pembinaan Karakter Siswa Dalam Membentuk Sikap 3S (senyum salam dan sapa)", Jurnal Pasca Sarjana Universitas Negeri Gorontalo, Vol. 2, No. 2 (2017).

\footnotetext{
${ }^{11}$ Nur Ainiyah "Pembentukan Karakter melalui Pendidikan Agama Islam" Jurnal Al-Ulum (Jurnal Studi-Studi Islam) IAIN Gorontalo, Vol. 13 No. 1 (Juni 2013), 25-38.
} 
Siti Nor Hayati, "Manfaat SholatDluha dalam Pembentukan Akhlakulkarimah Siswa", JurnalSpiritualita, Vol. 1, No. 1 Juni 2017

Zuchdi, Darmiyati. Pendidikan Karakter dalam Perspektif Teori dan Praktik, Yogyakarta: UNY Press, 2011. 